\title{
PERUBAHAN INTERAKSI MASYARAKAT MELALUI KONTAK SOSIAL DAN KOMUNIKASI SOSIAL DI DESA WISATA SINGOSAREN WUKIRSARI KECAMATAN IMOGIRI KABUPATEN BANTUL
}

\section{Social Interaction Changes of The Community Through Social Contact and Social Communication in Singosaren Wukirsari Tourism Village Imogiri District Bantul Regency}

Muhamad Rifki Ainul Adha*, Eko Murdiyanto, Siti Hamidah

Program Studi Agribisnis Fakultas Pertanian

Universitas Pembangunan Nasional "Veteran" Yogyakarta

Jl. SWK 104, Condongcatur, Kecamatan Depok, Kabupaten Sleman, Yogyakarta email korespondensi : mrifki68@gmail.com

Diterima tanggal : 18 Agustus 2019 ; Disetujui tanggal : 3 November 2019

\begin{abstract}
This research aims to (1) Examine the process of changing interaction through social contact. (2) Examine the process of changing interaction through social contact. This method used in case in this study was qualitative with a case of study approach. Determination of data sources was done purposively namely chairman of RT 04 \& Community of Singosaren, Chairman of Tansah Bedjo Youth Group and the active member of The Tansah Bedjo Youth Group. The data used in this study are primary data and secondary data. Data collection techniques with observation, interviews, and documentation by testing the validity of data using triangulation. Data analysis technique with collecting data, data reduction, data presentation and withdrawal of conclusion and verification. The results of the study concluded that Changes in interaction through social contact and social communication is a change of associative.
\end{abstract}

Keywords: Interaction, Social Communication, Social Contact

\begin{abstract}
ABSTRAK
Penelitian ini bertujuan untuk (1) Mengkaji terjadinya proses perubahan interaksi masyarakat melalui kontak sosial (2) Mengkaji terjadinya proses perubahan interaksi masyarakat melalui komunikasi sosial. Penelitian ini menggunakan pendekatan kualitatif. Teknik penentuan informan secara purposive yaitu Ketua RT 04 \& Masyarakat Dusun Singosaren, Ketua Kelompok Pemuda Tansah Bedjo, dan Anggota aktif Kelompok Pemuda Tansah Bedjo. Sumber Data yang digunakan adalah data primer dan data sekunder. Teknik pengumpulan data yaitu menggunakan observasi, wawancara dan dokumentasi dengan pengujian keabsahan data menggunakan triangulasi teknik. Teknik analisis data yaitu dengan mengumpulkan data, mereduksi data, penyajian data dan penarikan kesimpulan
\end{abstract}


dan verifikasi. Hasil penelitian ini memberikan kesimpulan bahwa Perubahan interaksi masyarakat melalui kontak sosial dan komunikasi sosial merupakan perubahan yang bersifat asosiatif.

Kata kunci: Interaksi, Kontak Sosial, Komunikasi Sosial

\section{PENDAHULUAN}

Dusun Singosaren merupakan dusun yang terletak di Desa Wukirsari, Kecamatan Imogiri, Kabupaten Bantul, Yogyakarta yang memiliki kondisi lingkungan masih asri. Dusun Singosaren memiliki tanah yang sangat subur sehingga penduduk di dusun ini rata-rata bekerja di sektor pertanian. Hal ini didukung oleh sarana pertanian berupa Selokan Tansah Bedjo yang digunakan sebagai saluran irigasi sawah, dan sebagai sarana budidaya ikan. Selokan Tansah Bedjo memiliki panjang 100 meter dengan lebar 1,2 meter, akan tetapi yang dimanfaatkan untuk budidaya ikan hanya 50 meter.

Selokan Tansah Bedjo mempunyai arti selalu beruntung. Hulu dari selokan tersebut bersumber dari Sungai Opak. Selokan ini memiliki kondisi air yang sangat bersih dan dipenuhi dengan ikan-ikan seperti ikan nila, ikan bawal, ikan tombro dan ikan koi. Selokan Tansah Bedjo dahulu merupakan selokan yang dipenuhi dengan sampah karena kebiasaan masyarakat yang sering membuang sampah rumah tangganya ke dalam Selokan Tansah Bedjo. Sampah yang dibuang di Selokan Tansah Bedjo yaitu sampah plastik, popok bayi, dan yang paling berbahaya adalah limbah minyak goreng karena dapat merusak dan membunuh ekosistem yang hidup di Selokan Tansah Bedjo. Tetapi dengan adanya Program Peduli Lingkungan, masyarakat Dusun Singosaren sudah tidak lagi membuang sampah-sampah rumah tanggnya ke dalam Selokan Tansah Bedjo karena mereka sudah sadar dan peduli akan pentingnya kebersihan lingkungan di Selokan Tansah Bedjo.

Program Peduli Lingkungan merupakan program yang dibuat oleh kelompok pemuda Dusun Singosaren yaitu Kelompok Pemuda Tansah Bedjo pada Februari 2017. Program Peduli Lingkungan mengajak seluruh masyarakat Dusun Singosaren untuk dapat peduli terhadap kebersihan lingkungan dan dapat memanfaatkan limbah minyak goreng agar dapat dimanfaatkan kembali untuk 
kebutuhan sehari-hari. Diharapkan dengan adanya Program Peduli Lingkungan para masyarakat tidak lagi menjadikan Selokan Tansah Bedjo menjadi tempat pembuangan sampah.

Setelah tujuan dari Program Peduli Lingkungan berhasil, kondisi Dusun Singosaren menjadi indah, bersih, sehat dan rapi. Kemudian, Dusun Singosaren diresmikan oleh Bupati Bantul Drs. H. Suharsono menjadi desa wisata pada 13 September 2017 dan setiap harinya dipenuhi oleh para wisatawan yang terkagum oleh keindahan dan kebersihan Selokan Tansah Bedjo tersebut. Dengan adanya desa wisata tersebut tentu menimbulkan beberapa perubahan-perubahan di dalam masyarakat. Perubahan tersebut terjadi pada interaksi sosial masyarakat karena adanya interaksi antara wisatawan dengan masyarakat yang menimbulkan interaksi baru di Desa Wisata Singosaren. Menurut Soekanto (2012) Interaksi sosial dapat diartikan sebagai hubungan sosial yang dinamis merupakan bentuk umum dari proses sosial. Interaksi sosial dapat didefinisikan sebagai hubungan timbal balik antara individu dengan individu, kelompok dengan kelompok, serta individu dengan kelompok.

Soekanto (2012) mengemukakan bahwa interaksi sosial tidak mungkin terjadi tanpa adanya dua syarat, yaitu :

1. Kontak Sosial, merupakan hubungan setiap pihak dalam berinteraksi baik dengan berbicara, tatap muka ataupun dengan bersalaman dan juga tidak selalu terjadi dengan cara interaksi atau hubungan fisik saja, karena orang bisa melakukan kontak sosial dengan pihak lain tanpa bersentuhan, contohnya melalui telepon, radio, surat, dan lain sebagainya.

2. Komunikasi Sosial, merupakan pengiriman dan penerimaan pesan atau berita antara dua orang atau lebih sehingga pesan yang dimaksud dapat dipahami. Hal terpenting dalam komunikasi sosial adalah kegiatan saling menafsirkan perilaku (pembicaraan, gerakan-gerakan fisik, atau sikap) dan perasaan-perasaan yang disampaikan.

Menurut Soekanto (2012), Interaksi sosial dibedakan menjadi dua bentuk, yaitu asosiatif dan disosiatif:

1. Asosiatif 
Interaksi sosial yang bersifat asosiatif akan mengarah pada bentuk penyatuan.

\section{Disosiatif}

Interaksi sosial yang bersifat disosiatif akan mengarah pada bentuk pemisahan.

Soekanto (2012) juga mengemukakan bahwa Perubahan dapat diketahui dengan membandingkan keadaan masyarakat dalam satu waktu dengan keadaan yang lampau. Oleh karena itu perlu dikaji mengenai perubahan interaksi masyarakat yang terjadi di Dusun Singosaren dengan adanya Desa Wisata Singosaren melalui kontak sosial dan komunikasi sosial.

\section{METODE PENELITIAN}

Lokasi penelitian berada di Desa Wisata Singosaren, Desa Wukirsari, Kecamatan Imogiri, Kabupaten Bantul, Yogyakarta karena desa wisata tersebut merupakan desa percontohan untuk desa wisata di Kabupaten Bantul yang berbasis Selokan Edukasi. Waktu penelitian dilakukan dari bulan Juni sampai dengan Agustus 2019. Jenis penelitian yang digunakan adalah penelitian kualitatif dengan pendekatan studi kasus. Fokus penelitian yang diamati ialah Perubahan interaksi sosial masyarakat di Desa Wisata Singosaren. Teknik penentuan informan dilakukan dengan cara purposive sampling yaitu teknik pengambilan sampel sumber data dengan pertimbangan tertentu, misalnya orang tersebut dianggap paling tahu tentang apa yang kita harapkan (Sugiyono, 2011). Subjek penelitian dalam penelitian ini adalah sumber informasi atau orang yang paling paham mengenai data yang dibutuhkan yaitu Ketua RT 04 Dusun Singosaren, Masyarakat Dusun Singosaren, Ketua Kelompok Pemuda Tansah Bedjo, dan Anggota aktif Kelompok Pemuda Tansah Bedjo.

Teknik pengumpulan data yang digunakan dalam penelitian kualitatif adalah observasi, wawancara, dan dokumentasi (Sugiyono, 2011). Dalam penelitian ini untuk menguji keabsahan data menggunakan triangulasi teknik untuk menguji kredibilitas data dilakukan dengan cara mengecek data kepada sumber yang sama dengan teknik yang berbeda (Sugiyono, 2011). Miles dan 
Adha et.al. / Jurnal Dinamika Sosial Ekonomi Vol.20 No.2, Desember 2019

Huberman (1984) dalam Sugiyono (2011) mengemukakan bahwa akivitas dalam analisis data kualitatif dilakukan secara interaktif dan berlangsung secara terus menerus sampai tuntas, sehingga datanya sudah jenuh. Analisis data yang dilakukan berupa data reduction, data display, dan conclusion drawing/verification.

\section{HASIL DAN PEMBAHASAN}

Setelah menjadi Desa Wisata Singosaren, Pada dasarnya masyarakat Dusun Singosaren dapat mengalami beberapa perubahan karena adanya Desa Wisata Singosaren. Perubahan tersebut terjadi pada interaksi sosial masyarakat Desa Wisata Singosaren melalui kontak sosial dan komunikasi sosial masyarakat Desa Wisata Singosaren. Perubahan tersebut dapat diketahui dengan membandingkan keadaan masyarakat sebelum adanya Desa Wisata Singosaren dengan setelah adanya Desa Wisata Singosaren. Hal tersebut sesuai dengan pernyataan Soekanto (2012) bahwa interaksi sosial tidak mungkin terjadi tanpa adanya dua syarat, yaitu kontak sosial dan komunikasi sosial. Perubahan dapat diketahui dengan membandingkan keadaan masyarakat dalam satu waktu dengan keadaan yang lampau.

\section{Kontak Sosial}

Kontak sosial merupakan sekumpulan proses aksi dan reaksi sosial dalam kehidupan masyarakat. Kontak sosial dapat terjadi secara langsung dan tidak langsung. Kontak sosial langsung terjadi apabila yang mengadakan hubungan langsung bertemu dan berhadapan muka, sedangkan kontak sosial tidak langsung terjadi apabila hubungan sosial terjadi melalui suatu perantara yaitu bisa menggunakan media penunjang interaksi berupa teknologi. Hal tersebut sesuai dengan pernyataan Mulyaningsih (2014) bahwa kontak sosial tidak sekedar bergantung pada tindakan, akan tetapi juga tanggapan atau reaksi terhadap tindakan tersebut. Hasil penelitian Sihabudin (2010) juga menyatakan bahwa kontak sosial dapat dikatakan sebagai kegiatan komunikasi interpersonal, hubungan beberapa orang yang terjadi diantara mereka dapat dikatakan sebagai 
komunikasi kelompok, kontak dengan media apakah surat kabar, televisi dan lainlain dapat dikatakan sebagai proses komunikasi massa. Artinya kontak bisa saja terjadi baik dengan manusia maupun benda.

Dengan demikian, kontak sosial di Desa Wisata Singosaren dapat terjadi melalui interaksi antar masyarakat dan media penunjang interaksi yang ada di dalam masyarakat.

1. Interaksi Antar Masyarakat

Perubahan kontak sosial dapat dilihat melalui Interaksi antar masyarakat sebelum dan setelah adanya Desa Wisata Singosaren. Hal tersebut sesuai dengan pernyataan Mulyadi (2015) bahwa perubahan dapat diketahui bila kita melakukan suatu perbandingan dengan menelaah suatu masyarakat pada masa tertentu dengan keadaan masyarakat pada waktu yang lampau.

Sebelum adanya Desa Wisata Singosaren interaksi antar masyarakat Dusun Singosaren paling banyak terjadi ketika ada pertemuan kegiatan organisasi, acara besar desa, acara hajatan serta budaya tegur dan saling sapa saat masyarakat bertemu dijalan.

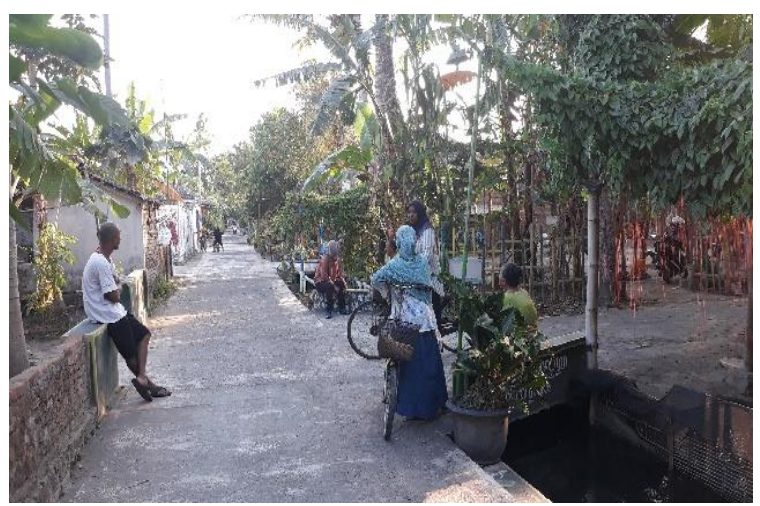

Gambar 1. Interaksi Masyarakat di Desa Wisata Singosaren

Berdasarkan Gambar 1 dapat dilihat bahwa, Setelah adanya Desa Wisata Singosaren masyarakat Dusun Singosaren semakin sering bertemu dan berinteraksi tidak hanya di kegiatan organisasi, acara besar desa dan acara hajatan saja. Budaya tegur dan sapa juga masih sering dilakukan dan tidak ada perubahan interaksi.

2. Media Penunjang Interaksi Masyarakat 
Perubahan kontak sosial dapat dilihat melalui media penunjang interaksi masyarakat sebelum dan setelah adanya Desa Wisata Singosaren. Hal tersebut sesuai dengan pernyataan Mulyadi (2015) bahwa perubahan dapat diketahui bila kita melakukan suatu perbandingan dengan menelaah suatu masyarakat pada masa tertentu dengan keadaan masyarakat pada waktu yang lampau.

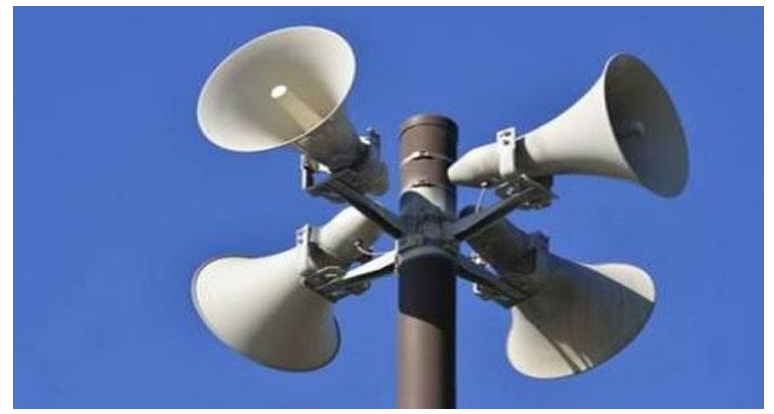

Gambar 2. Toa Masjid Al-A’la Dusun Singosaren

Berdasarkan Gambar 2 dapat dilihat bahwa, Sebelum adanya Desa Wisata Singosaren masyarakat menggunakan toa masjid untuk mengumumkan informasi tentang kegiatan desa kepada seluruh masyarakat. Masyarakat juga sudah menggunakan Handphone, tetapi masyarakat hanya menggunakan fitur SMS dan Telefon, sehingga komunikasi tidak terjalin secara maksimal dan keseluruhan.

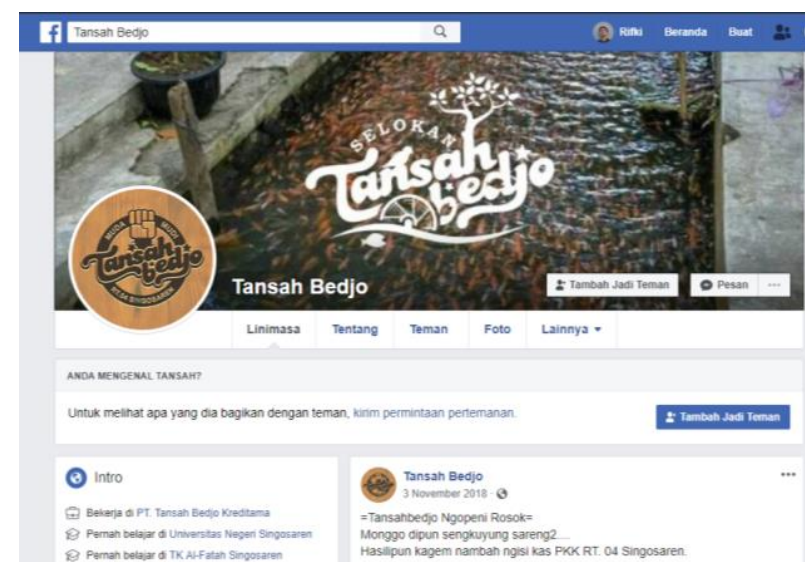

Gambar 3. Laman Facebook Kelompok Pemuda Tansah Bedjo

Berdasarkan Gambar 3 dapat dilihat bahwa, Setelah adanya Desa Wisata Singosaren masyarakat masih menggunakan toa masjid tetapi tidak sesering sebelum adanya Desa Wisata Singosaren. Masyarakat menjadi sering 
menggunakan aplikasi Whatsapp dan Facebook untuk mengabari seluruh masyarakat Dusun Singosaren dengan mudah melalui Fitur Group Desa Wisata Singosaren.

Soekanto (2012) mengemukakan bahwa proses perubahan interaksi sosial terbagi dalam dua bentuk yaitu perubahan interaksi asosiatif dan perubahan interaksi disosiatif. Proses perubahan interaksi asosiatif merupakan hubungan masyarakat dalam bentuk penyatuan, sedangkan perubahan disosiatif adalah interaksi sosial yang mengarah pada bentuk pemisahan. Perubahan interaksi sosial masyarakat melalui kontak sosial yang terjadi di Desa Wisata Singosaren merupakan bentuk proses perubahan yang bersifat asosiatif, karena di dalam perubahan tersebut mengarah pada penyatuan masyarakat Desa Wisata Singosaren.

\section{Komunikasi Sosial}

Komunikasi sosial merupakan suatu proses interaksi antara individu dengan individu, individu dengan kelompok atau kelompok dengan kelompok yang saling memberikan pengaruh satu sama lainnya, pengaruh tersebut dapat mengembangkan pengetahuan individu atau kelompok tersebut. Hal tersebut sesuai dengan pernyataan Mudjiono (2012) bahwa komunikasi sosial terjadi antar individu dalam kehidupannya di masyarakat yang memiliki konteks dalam segala dimensi kehidupan manusia. Seluruh dimensi kehidupan manusia dipenuhi dengan komunikasi. Komunikasi sosial mengisyaratkan bahwa berkomunikasi itu penting untuk membangun konsep diri, aktualisasi diri, untuk kepentingan hidup, untuk memperoleh kebahagiaan, terhindar dari tekanan dan ketegangan.

Dengan demikian, komunikasi sosial dapat terjadi melalui alat untuk berinteraksi antar masyarakat, pola pikir masyarakat, dan organisasi sosial yang ada di dalam masyarakat karena dalam organisasi sosial di Desa Wisata Singosaren, individu dapat mempengaruhi pola pikir kelompok atau bahkan sebaliknya menggunakan alat untuk berinteraksi.

1. Alat untuk berinteraksi antar masyarakat 
Perubahan komunikasi sosial dapat dilihat melalui alat untuk berinteraksi antar masyarakat berupa bahasa sebelum dan setelah adanya Desa Wisata Singosaren. Hal tersebut sesuai dengan pernyataan Mulyadi (2015) bahwa perubahan dapat diketahui bila kita melakukan suatu perbandingan dengan menelaah suatu masyarakat pada masa tertentu dengan keadaan masyarakat pada waktu yang lampau.

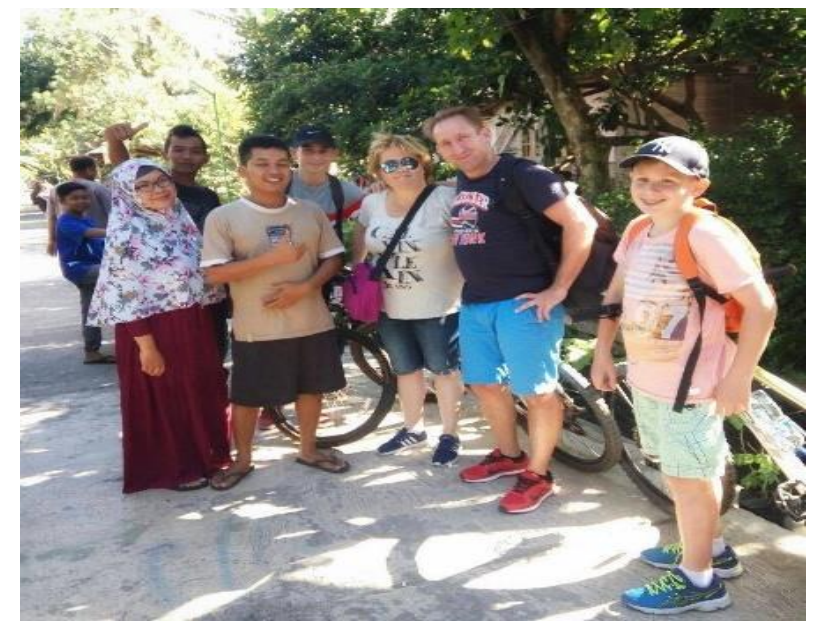

Gambar 4. Wisatawan Asing dan Masyarakat Desa Wisata Singosaren

Berdasarkan Gambar 4 dapat dilihat bahwa, sebelum adanya Desa Wisata Singosaren masyarakat Dusun Singosaren menggunakan bahasa Jawa Kromo dan Jawa Ngoko sebagai alat untuk berinteraksi. Sedangkan setelah adanya Desa Wisata Singosaren alat Interaksi antar masyarakat masih menggunakan Bahasa Jawa Kromo atau Ngoko. Bahasa Indonesia, Bahasa Inggris dan bahasa luar negeri lainnya digunakan untuk berkomunikasi dengan para wisatawan.

2. Pola pikir masyarakat

Perubahan komunikasi sosial dapat dilihat melalui pola pikir masyarakat sebelum dan setelah adanya Desa Wisata Singosaren. Hal tersebut sesuai dengan pernyataan Mulyadi (2015) bahwa perubahan dapat diketahui bila kita melakukan suatu perbandingan dengan menelaah suatu masyarakat pada masa tertentu dengan keadaan masyarakat pada waktu yang lampau.

Sebelum adanya Desa Wisata Singosaren :

a) Masyarakat belum bisa memanfaatkan peluang untuk berjualan makanan. 
b) Para orang tua tidak mampu untuk membayar sekolah anak-anaknya, sehingga menyebabkan anak-anak malas untuk sekolah dan memilih untuk bekerja.

c) Masyarakat kebingungan dalam membuang sampah, sehingga di buang ke Selokan Tansah Bedjo.

d) Masyarakat hanya menggunakan minyak goreng untuk memasak, kemudian jika sudah tidak digunakan minyak goreng tersebut dibuang ke Selokan Tansah Bedjo.

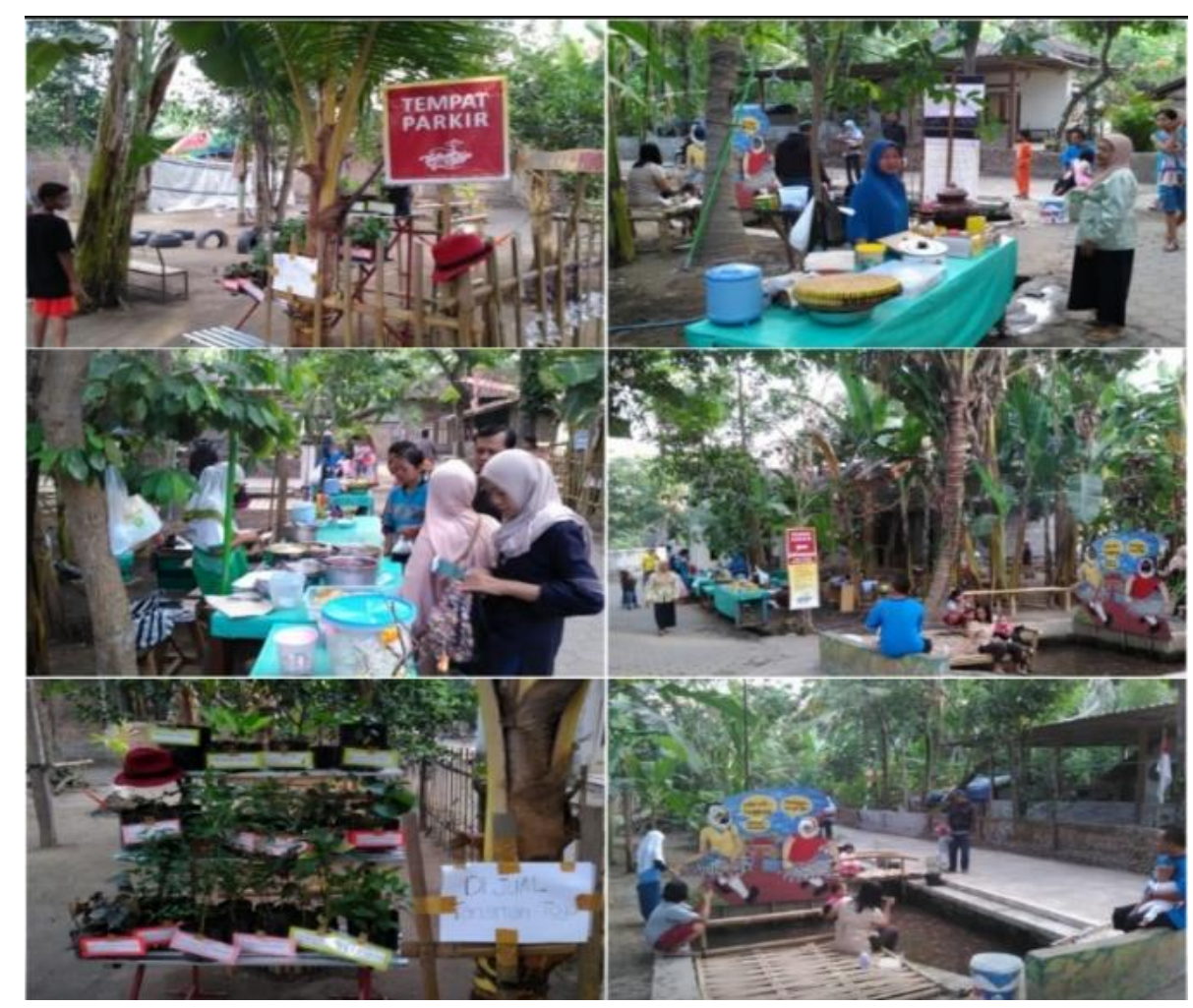

Gambar 5. Toko oleh-oleh dan warung makan khas Desa Wisata Singosaren

Berdasarkan Gambar 5 dapat dilihat bahwa, Setelah adanya Desa Wisata Singosaren :

a) Masyarakat berani memanfaatkan peluang untuk berjualan makanan.

b) Masyarakat menggunakan jasa angkut sampah dan masyarakat menjadi sadar akan kebersihan lingkungan

c) Orang tua sudah bisa membayar anaknya sekolah, dan anak-anak menjadi semangat sekolah untuk mengembangkan daerahnya 
d) Masyarakat dapat membuat sabun dari minyak goreng bekas, dan tidak lagi membuang ke Selokan Tansah Bedjo.

3. Organisasi sosial yang ada di dalam masyarakat

Perubahan komunikasi sosial dapat dilihat melalui organisasi sosial yang ada didalam masyarakat sebelum dan setelah adanya Desa Wisata Singosaren. Hal tersebut sesuai dengan pernyataan Mulyadi (2015) bahwa perubahan dapat diketahui bila kita melakukan suatu perbandingan dengan menelaah suatu masyarakat pada masa tertentu dengan keadaan masyarakat pada waktu yang lampau.

Sebelum adanya Desa Wisata Singosaren partisipasi anggota organisasi masyarakat masih cukup besar dan masyarakat selalu mengikuti kegiatan tersebut kecuali yang berhalangan hadir dengan alasan yang logis.

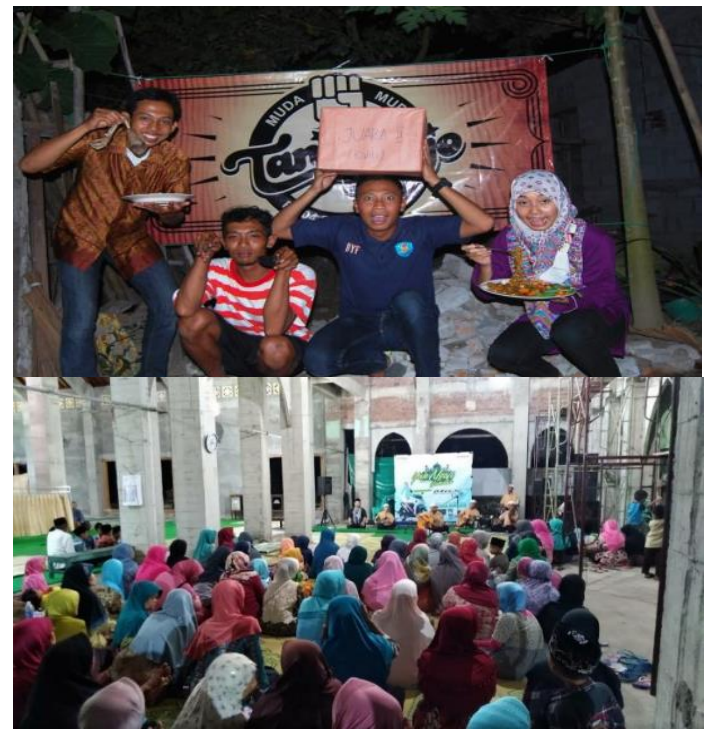

Gambar 6. Organisasi Sosial di Desa Wisata Singosaren

Berdasarkan Gambar 6 dapat dilihat bahwa, Setelah adanya Desa Wisata Singosaren Kelompok Pemuda Tansah Bedjo menjadi lebih aktif mengadakan pertemuan untuk mengembangkan, mengelola, dan mempromosikan Desa Wisata Singosaren. Sedangkan, Partisipasi Kelompok Pengajian yang ke masjid menjadi menurun karena beberapa anggota Kelompok Pengajian terfokus pada dagangan jualan di Desa Wisata Singosaren. 
Soekanto (2012) mengemukakan bahwa proses perubahan interaksi sosial terbagi dalam dua bentuk yaitu perubahan interaksi asosiatif dan perubahan interaksi disosiatif. Proses perubahan interaksi asosiatif merupakan hubungan masyarakat dalam bentuk penyatuan, sedangkan perubahan disosiatif adalah interaksi sosial yang mengarah pada bentuk pemisahan. Perubahan interaksi sosial masyarakat melalui komunikasi sosial yang terjadi di Desa Wisata Singosaren merupakan bentuk proses perubahan yang bersifat asosiatif, karena di dalam perubahan tersebut mengarah pada penyatuan masyarakat Desa Wisata Singosaren.

\section{KESIMPULAN}

Proses perubahan interaksi masyarakat melalui kontak sosial terjadi pada interaksi antar masyarakat dan media penunjang interaksi. Proses perubahan interaksi masyarakat melalui komunikasi sosial terjadi pada alat untuk berkomunikasi, pola pikir dan organisasi sosial. Proses perubahan interaksi masyarakat melalui kontak sosial dan komunikasi sosial bersifat interaksi asosiatif karena di dalam perubahan tersebut mengarah pada penyatuan masyarakat Desa Wisata Singosaren.

\section{SARAN}

Pengajian perlu diadakan malam hari dan bukan saat hari libur agar partisipasi komunikasi sosial anggota Kelompok Pengajian tidak semakin menurun. Karena ketika hari libur, beberapa anggota Kelompok Pengajian berjualan di Desa Wisata Singosaren.

\section{DAFTAR PUSTAKA}

Mudjiono, Yoyon. (2012). Komunikasi Sosial. Jurnal Ilmu Komunikasi 2(1) : 99112.

Mulyadi, M. (2015). Perubahan Sosial Masyarakat Agraris Ke Masyarakat Industri Dalam Pembangunan Masyarakat Di Kecamatan Tamalate Kota Makassar. Jurnal Bina Praja 7 (4) : 311-322.

Mulyaningsih, I.E. (2014). Pengaruh Interaksi Sosial Keluarga, Motivasi Belajar, dan Kemandirian Belajar Terhadap Prestasi Belajar. Jurnal Pendidikan dan Kebudayaan 20 (4) : 441-451. 
Adha et.al. / Jurnal Dinamika Sosial Ekonomi Vol.20 No.2, Desember 2019

Sihabudin, Ahmad. (2010). Pengaruh Interaksi Sosial Komunitas Adat Budaya Luar Terhadap Persepsinya pada Kebutuhan Keluarga. Jurnal Penyuluhan. 6(1) : 96-107.

Soekanto, S. (2012). Sosiologi : Suatu Pengantar. Jakarta: Yayasan Penerbit Universitas Indonesia.

Sugiyono. (2011). Metode Penelitian Kuantitatif, Kualitatif, dan $R \&$ D. Bandung: Alfabeta. 